\title{
Journal of Animal Diversity
}

\section{Shell utilization pattern of the Hermit crab Clibanarius rhabdodactylus Forest, 1953 on rocky shores of the Saurashtra coast, Gujarat State, India}

\author{
Pooja R Patel $^{1 \oplus}$, Krupal J Patel $^{2}{ }^{\odot}$, Kauresh D Vachhrajani ${ }^{3 \odot}$ and Jigneshkumar N Trivedi ${ }^{4} \odot$ \\ ${ }^{1,4}$ Department of Life Sciences, Hemchandracharya North Gujarat University, Patan-384265, Gujarat, India \\ ${ }^{2,3}$ Marine Biodiversity and Ecology Laboratory, Department of Zoology, The Maharaja Sayajirao University \\ of Baroda, Vadodara-390002, Gujarat, India \\ *Corresponding author jntrivedi26@yahoo.co.in
}

Received: 7 November 2020 Accepted: 16 January 2021 Published online: 6 March 2021

\begin{abstract}
The present study deals with gastropod shell utilization of the hermit crab, Clibanarius rhabdodactylus Forest on the rocky intertidal zone of the Saurashtra coast, Gujarat State, India. Collection of the specimens was carried out using a hand-picking method in June and December 2018 during low tide. The hermit crab weight (HW) and shield length (SL) were measured and sorted in different class intervals of $1 \mathrm{~mm}$ each. Gastropod shells were identified and morphological variables such as shell dry weight (DW), shell length (SHL), shell volume (SHV), shell aperture length (SAL), and shell aperture width (SAW) were recorded. A total of 2000 individuals of C. rhabdodactylus were collected, occupying 29 different species of gastropod shells. Males and non-ovigerous females occupied a greater number of gastropod shell species (25 and 27 respectively) as compared to ovigerous females (23 species). Males and ovigerous females preferred larger shells as compared to non-ovigerous females. Cerithium caeruleum (Sowerby II) (67.1\%) was the highest occupied gastropod shell species followed by Lunella coronata (Gmelin), Tenguella granulata (Duclos) and Turbo bruneus (Roding). Regression analysis showed a moderate relationship between the different morphological variables of hermit crabs and gastropod shells; the highest values of coefficient of determination were obtained between hermit wet weight and gastropod shell dry weight. The values of relationship between different morphological variables of hermit crabs and gastropod shells suggest that shell architecture has a significant impact on shell utilization patterns of $C$. rhabdodactylus.
\end{abstract}

Key words: Gastropods diversity, Hermit crab morphology, shell architecture, shell selection

\section{Introduction}

Hermit crabs belong to the superfamily Paguroidea of order Decapoda. They are abundantly found in intertidal and subtidal areas (Reese, 1969) and occupy empty gastropod shells to protect their noncalcified abdomen (Vance, 1972). Hermit crabs occupy either empty shells (Reese, 1969) or by removing the gastropod from the shell (Elwood and Neil, 1992). The selection of shell is primarily dependent upon shell availability (Kellogg, 1977) while shell species, shell internal volume, weight, aperture width and length, and shell condition are also important factors for shell selection (Abrams, 1978; Angel, 2000; Dominciano and Mantelatto, 2004; Biagi et al., 2006; Bach and Hazlett, 2009). Occupying empty shells provides shelter from various physical factors (Hazlett, 1966) and biological stress (Bertness, 1982). Shell morphology has various advantages and disadvantages to hermit 
crab species. For example, large and heavy shells provide more space for egg incubation and protection from predators, but they also reduce reproductive success and increase energy consumption from locomotion (Bertness, 1981; Wada et al., 1997; Osorno et al., 2005; Arguelles et al., 2009). Hermit crabs need to occupy larger shells as their size increases, and therefore, they constantly search for a suitable gastropod shell (Bertness, 1981).

The pattern of shell use is well-known to be dependent on shell availability (Turra and Leite, 2001; Argüelles-Ticó et al., 2010) and shell preference (Bertness, 1980; Mantelatto et al., 2007). Hermit crabs choose shells according to species or shape (Mantelatto et al., 2007), size (Hazlett, 1992), shell condition (Pechenik et al., 2001), the previous experience of the crab (Meireles et al., 2008), and the developmental and reproductive stage of the crab (Elwood et al., 1979). The size, type and condition of the shell used by a hermit crab have been shown to be determinants of its growth, fecundity, motility, and survivorship (Bertness, 1981; Bach and Hazlett, 2009). Accordingly, hermit crabs are not only selective for the shell size (Turra and Leite, 2004; Mantelatto et al., 2007) and weight (Briffa and Elwood, 2005), but also for shells of particular gastropod species (shell type) (Vance, 1972; Hazlett, 1981). Preferred shell types have been shown to increase hermit crab fitness relative to non-preferred shell types (Dominciano et al., 2009). In hermit crabs particularly, shell selection is not by chance but based on adequacy and availability of resources (Reese, 1962; Conover, 1978), and is affected by both shell size and species (Abrams, 1978; Mantelatto and Dominciano, 2002; Mantelatto and Meireles, 2004).

The Gujarat coastline is $1650 \mathrm{~km}$ long and can be divided into three major coastal regions viz. the Gulf of Kachchh, the Gulf of Khambhat and the Saurashtra coast (Trivedi et al., 2015). The coastline of Saurashtra is $800 \mathrm{~km}$ long with narrow, rocky, intertidal habitats (Trivedi, 2015). Total 75 species belonging to 43 genera and 26 families of crustaceans including barnacles, brachyuran crabs, anomuran crabs, prawns and lobsters has been recorded from the study area (Trivedi et al., 2015). In total, 18 species (4 genera, 2 families) of hermit crabs are reported from the Gujarat State (Kachhiya et al., 2017; Trivedi and Vachhrajani, 2017; Patel et al., 2020). However, ecological studies like intertidal distribution (Vaghela and Kundu, 2012), effect of abiotic and biotic factors on populations (Desai and Mansuri, 1989) and shell utilization patterns (Trivedi and Vachhrajani, 2014) are usually carried out on species like Clibanarius zebra (Dana) and Diogenes custos (Fabricius) (Patel et al., 2020).

Clibanarius rhabdodactylus is a rarer species of hermit crab found on rocky intertidal habitats of the Philippines (Malay et al., 2018), Japan (Osawa and
Yoshida, 2009) and the Saurashtra coast, Gujarat State in India (Kachiya et al., 2017). Ecological aspects of this species are not studied yet, and so, the present study is an attempt to understand the ecology of C. rhabdodactylus on rocky shores of the Saurashtra coast, Gujarat State.

The study aims to analyze the relationship between the morphology of $C$. rhabdodactylus and various morphological parameters of gastropod shells utilized by the species.

\section{Material and Methods}

\section{Study area}

The present study was conducted in the rocky intertidal zone, located on the Saurashtra coast, at Veraval $\left(20^{\circ} 54^{\prime} 37^{\prime \prime N}, 70^{\circ} 21^{\prime} 04^{\prime \prime E}\right)$ (Fig. 1). The width of the low tide exposed rocky intertidal zone varies from 60 to $150 \mathrm{~m}$. Clibanarius rhabdodactylus occurs in high abundance on the rocky shores of the study site where it occupies rock crevices and shallow tide pools found in the upper and middle intertidal zone (Patel et al., unpublished data).

\section{Sampling method}

The specimens of $C$. rhabdodactylus were handpicked randomly during low tide in June 2018 and December 2018. All the specimens were kept in an ice box and brought to the laboratory for further analysis. Hermit crabs were gently removed from their shells by slowly twisting the crab against the direction of the shell spiral and only intact individuals were used for the study. The gender of each individual was identified using a stereo microscope (Metlab PST 901) and further categorized into male, non-ovigerous female and ovigerous female.

Hermit crabs were sorted into different size classes on the basis of their shield length (SL). Two morphological characteristics, hermit crab weight (HW) (0.01 g) using a digital scale (Mezire mini accuracy pocket balance, $0.01 \mathrm{~g}$ to $200 \mathrm{~g}$ ) and shield length $(0.01 \mathrm{~mm})$, from the midpoint of the rostrum to the midpoint of the posterior margin of the shield (Sant'anna et al., 2006) using vernier callipers (Mitutoyo Absolute AOS Digimatic, $0.01 \mathrm{~mm}$ to 150 $\mathrm{mm}$ ) were measured for each individual. The gastropod shells were identified to species level using a monograph by Apte (2014). For gastropod shells, five traits were measured: shell total length (SHL) $(0.01 \mathrm{~mm})$, from the tip of the apex to the base; shell aperture length (SAL) $(0.01 \mathrm{~mm})$, maximum length of the opening of a gastropod shell parallel to the shell length; shell aperture width (SAW) $(0.01 \mathrm{~mm})$, maximum length of the opening perpendicular to aperture length (Chiu et al., 2002). For dry weight (DW) $(0.01 \mathrm{~g})$, the shells were dried in a laboratory oven at $60{ }^{\circ} \mathrm{C}$ for $24 \mathrm{~h}$ and weighed (Argüelles-Ticó et al., 2010). For shell volume (SHV) the empty shell was filled with water using a syringe $(0.1 \mathrm{ml})$ to the 
edge of the aperture and the total volume of water filled is considered as the shell volume $\left(\mathrm{mm}^{3}\right)$. The shell traits were considered dependent and were correlated with the hermit crab morphometric variables (SL and $\mathrm{HW}$ ), taken as independent variables.

For size distribution of different sexes of the hermit crabs, individuals of each sex were grouped into different size class intervals of $1 \mathrm{~mm}$ shield length ranging from $0.1 \mathrm{~mm}$ to $8 \mathrm{~mm}$. The Regression analysis was carried out by the power function ( $\mathrm{y}=$ $\left.a x^{b}\right)$, with the best fit expressed by the determination coefficient $\left(\mathrm{R}^{2}\right)$ to find out the relationship between the different morphological variables of the hermit crab and gastropod shell morphology (Sant'Anna et al., 2006). Variation in mean values of shield length of different sexes of hermit crab was analysed using a one-way ANOVA at a 5\% significance level. The shell species occupation rate was estimated as a percentage and the Chi square test $\left(\chi^{2}\right)$ was used to compare the occupancy rates of different shell species at a $5 \%$ significance level.
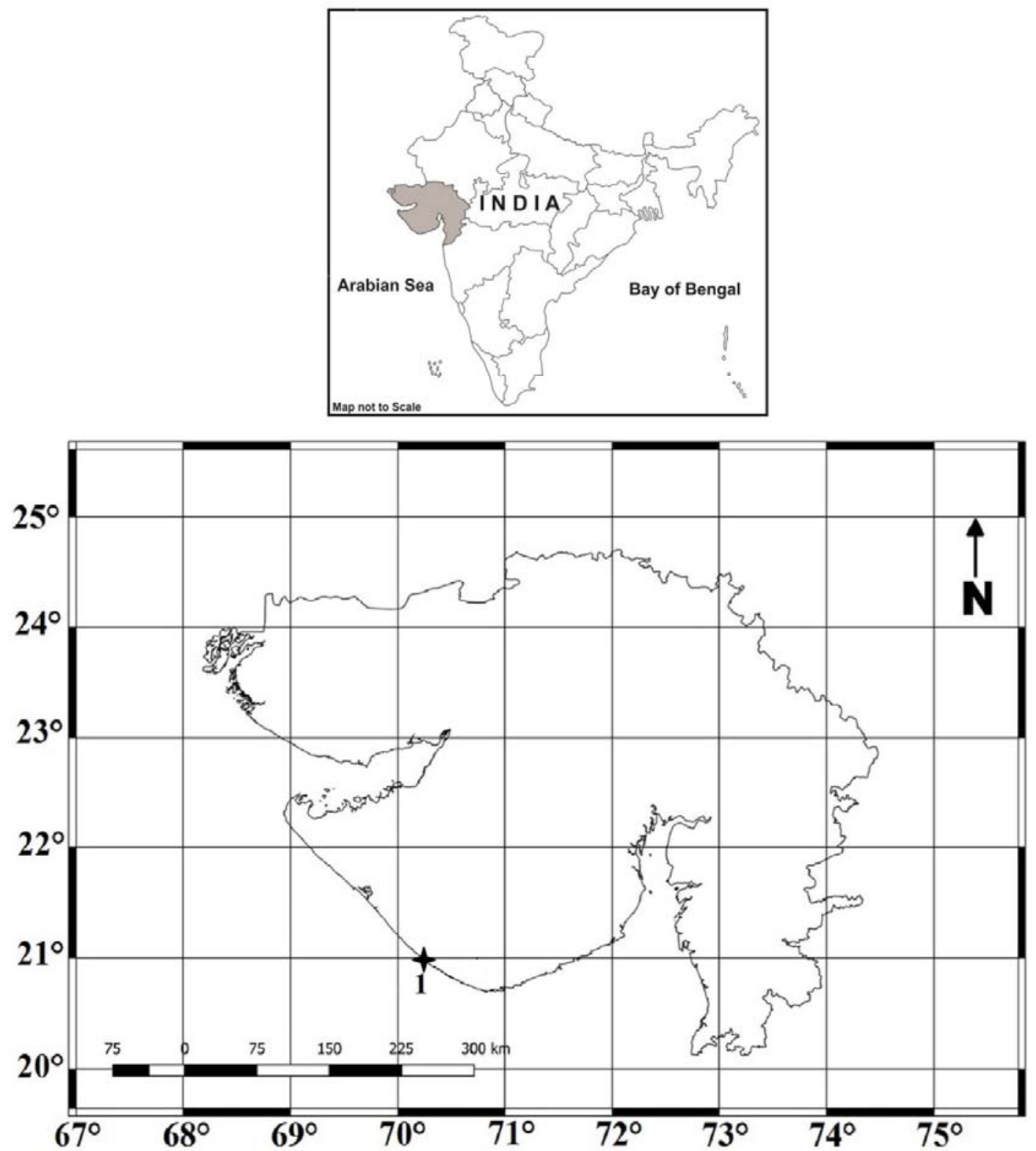

Figure 1: Map of study area. 1. Veraval, Saurashtra coast, Gujarat, India. 


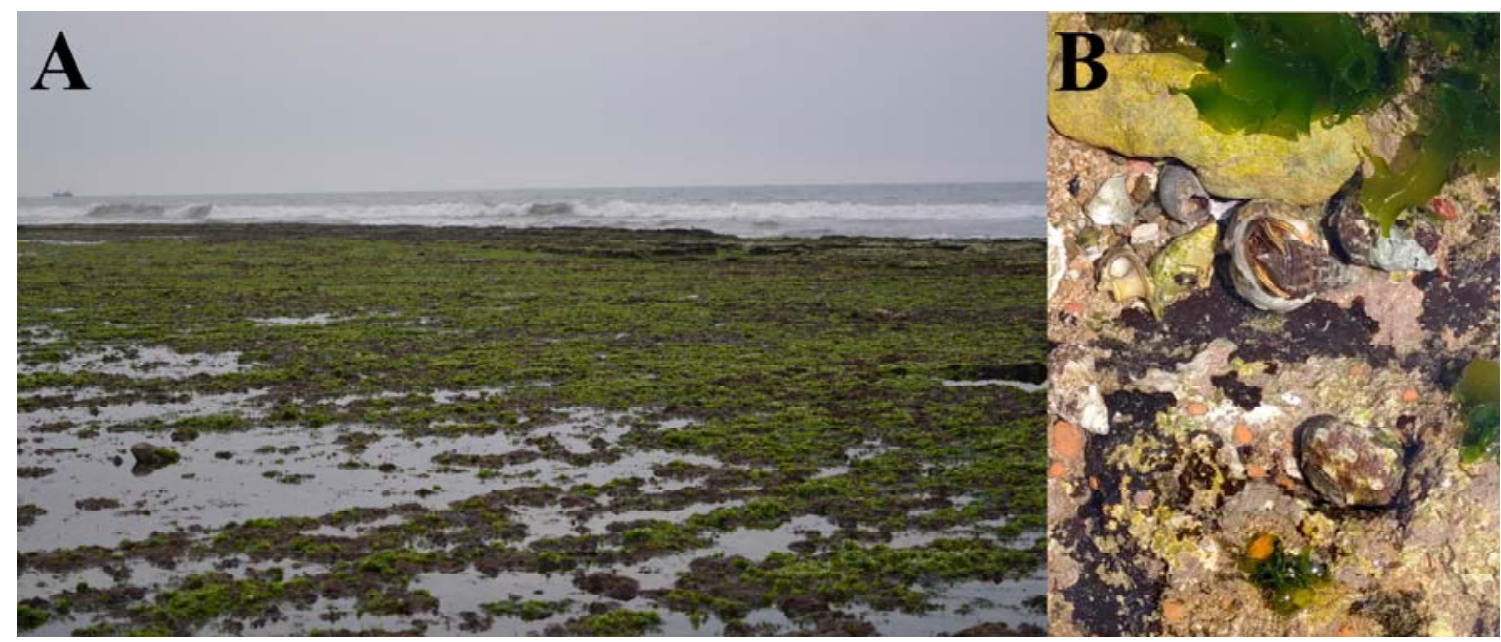

Figure 2: Rocky intertidal habitat of Clibanarius rhabdodactylus (A); microhabitat of Clibanarius rhabdodactylus in Veraval, Saurashtra coast, Gujarat, India (B).

\section{Results}

A total of 2000 individuals of $C$. rhabdodactylus were collected during the study period - 680 specimens were males (34\%), 611 were non-ovigerous females (30.55\%), and 709 were ovigerous females (35.45\%). Males of C. rhabdodactylus were significantly larger than females $(\mathrm{F}=388.51, \mathrm{df}=1999, p<0.001)($ Table 1$)$.

Table 1: Carapace shield length values of Clibanarius rhabdodactylus in Veraval, Saurashtra coast, Gujarat, India. $(* * * p<0.001)$.

\begin{tabular}{lccc}
\hline Sex & $\begin{array}{c}\text { Minimum } \\
(\mathbf{m m})\end{array}$ & $\begin{array}{c}\text { Maximum } \\
(\mathbf{m m})\end{array}$ & $\begin{array}{c}\text { Mean } \pm \\
\text { SD }\end{array}$ \\
\hline Male & 1.87 & 7.53 & $\begin{array}{c}4.48 \pm \\
\text { Non- }\end{array}$ \\
$\begin{array}{l}\text { Novigerous } \\
\text { female }\end{array}$ & 0.9 & 6.64 & $3.46 \pm$ \\
$\begin{array}{l}\text { Ovigerous } \\
\text { female }\end{array}$ & 2.32 & 6.22 & $0.64 * * *$ \\
\hline & & & $\begin{array}{c}3.63 \pm \\
1.50^{* * *}\end{array}$ \\
\hline
\end{tabular}

Male individuals were recorded in all size classes ( 0.1 to $8.0 \mathrm{~mm}$ ) with a maximum number of individuals recorded in the 4.0 to $5.0 \mathrm{~mm}$ size class. Nonovigerous females were recorded from 1.0 to $4.0 \mathrm{~mm}$ size classes with the maximum number of individuals recorded in the 3.0 to $4.0 \mathrm{~mm}$ size class. Ovigerous females were recorded in the 2.0 to $5.0 \mathrm{~mm}$ size classes with the maximum number of individuals recorded in the 3.0 to $4.0 \mathrm{~mm}$ size class (Fig. 3).

Clibanarius rhabdodactylus was found occupying 29 species (males: 25 species, non-ovigerous females: 27 species, ovigerous females: 23 species) of gastropod shells in different percentage rates of occupation. Out of 29 species of gastropod shells, five species were highly occupied by $C$. rhabdodactylus (Table 2).

Cerithium caeruleum Sowerby II (67.1\%) was highly occupied by C. rhabdodactylus followed by Lunella coronata (Gmelin) (6.7 \%), Tenguella granulata (Duclos) (4.8\%), Turbo bruneus (Roding) (3.8\%) and Pollia undosa (Linnaeus) (2.4\%) (Table 2). The variation in percentage occupation of these five species of gastropod was significant $\left(\chi^{2}=184.58\right.$, $p<0.0001$ ). The remaining gastropod species (termed “others”) contributed $15.2 \%$ of total gastropod shell occupation and their occupation percentage varied from $1.6 \%$ to $0.1 \%$ (Table 2). The percentage occupation of the five highly occupied gastropod shell species also varied significantly for the different sexes of C. rhabdodactylus (males, $\chi^{2}=60.44, p<$ 0.0001; non-ovigerous females, $\chi^{2}=263.97, p<$ 0.0001 ; ovigerous females, $\left.\chi^{2}=276.0, p<0.0001\right)$. It was also observed that out of the five most commonly occupied shells, Cerithium caeruleum was occupied maximally by all the sexes whereas the second most preferred shell by males was Lunella coronata by females it was Tenguella granulata.

Cerithium caeruleum shells were utilized by $C$. rhabdodactylus individuals recorded in size classes ranging from 0.1 to $7.0 \mathrm{~mm}$. Lunella coronata and $T$. granulata shells were commonly utilized by $C$. rhabdodactylus individuals recorded in size classes ranging from 2.0 to $7.0 \mathrm{~mm}$ with maximum utilization recorded in size classes 6.0-7.0 and 3.0$4.0 \mathrm{~mm}$, respectively. Turbo bruneus and $P$. undosa shells were commonly utilized by larger individuals of C. rhabdodactylus, recorded in size classes ranging from 3.0 to $8.0 \mathrm{~mm}$, with maximum utilization recorded in size classes 7.0-8.0 and 4.0$5.0 \mathrm{~mm}$, respectively (Fig. 4). 
Shell utilization pattern of the Hermit crab Clibanarius rhabdodactylus Forest, 1953 on rocky shores...

Table 2: Gastropod shell occupation by Clibanarius rhabdodactylus. (N: Number= 2000; M= Male; F= Non-ovigerous female; OF= Ovigerous Female).

\begin{tabular}{|c|c|c|c|c|c|c|c|c|c|}
\hline Gastropod Family & Gastropod species & $\mathbf{N}$ & $\%$ & $\mathbf{M}$ & $\%$ & $\mathbf{F}$ & $\%$ & OF & $\%$ \\
\hline Cerithiidae J. Fleming, 1822 & Cerithium caeruleum Sowerby II, 1855 & 1342 & 67.1 & 270 & 39.7 & 480 & 78.6 & 592 & 83.5 \\
\hline Turbinidae Rafinesque, 1815 & Lunella coronata (Gmelin,1791) & 134 & 6.7 & 121 & 17.8 & 11 & 1.8 & 2 & 0.3 \\
\hline Muricidae Rafinesque, 1815 & Tenquella aranulata (Duclos, 1832) & 96 & 4.8 & 5 & 0.7 & 36 & 5.9 & 55 & 7.8 \\
\hline Turbinidae Rafinesque, 1815 & Turbo bruneus (Roding, 1798) & 77 & 3.8 & 70 & 10.3 & 6 & 1.0 & 1 & 0.1 \\
\hline \multirow[t]{2}{*}{ Pisaniidae Gray, 1857} & Pollia undosa (Linnaeus, 1758) & 48 & 2.4 & 38 & 5.6 & 6 & 1.0 & 4 & 0.6 \\
\hline & Others & 303 & 15.2 & 176 & 25.9 & 72 & 11.8 & 55 & 7.8 \\
\hline \multirow[t]{4}{*}{ Cerithiidae Fleming, 1822} & Cerithium columna Sowerby I, 1834 & 2 & 0.1 & 0 & 0 & 1 & 0.2 & 1 & 0.1 \\
\hline & Cerithium coralium Kiener, 1841 & 4 & 0.2 & 0 & 0 & 3 & 0.5 & 1 & 0.1 \\
\hline & Cerithium echinatum Lamarck, 1822 & 6 & 0.3 & 1 & 0.1 & 2 & 0.3 & 3 & 0.4 \\
\hline & Clypeomorus batillariaeformis Habe and Kosuge, 1966 & 7 & 0.4 & 2 & 0.3 & 4 & 0.7 & 1 & 0.1 \\
\hline Chilodontaidae Wenz, 1938 & Euchelus asper (Gmelin, 1791) & 20 & 1 & 15 & 2.2 & 4 & 0.7 & 1 & 0.1 \\
\hline Cymatiidae Iredale, 1913 & Gyrineum natator (Roding, 1798) & 13 & 0.7 & 10 & 1.5 & 2 & 0.3 & 1 & 0.1 \\
\hline Horaiclavidae Bouchet, Kantor, Sysoev and Puillandre, 2011 & Paradrillia patruelis (Smith, 1875) & 6 & 0.3 & 0 & 0 & 1 & 0.2 & 5 & 0.7 \\
\hline Mitridae Swainson, 1831 & Mitra scutulata (Gmelin, 1791) & 3 & 0.2 & 1 & 0.1 & 2 & 0.3 & 0 & 0 \\
\hline \multirow[t]{10}{*}{ Muricidae Rafinesque, 1815} & Chicoreus brunneus (Link, 1807) & 27 & 1.4 & 26 & 3.8 & 1 & 0.2 & 0 & 0 \\
\hline & Chicoreus maurus (Broderip, 1833) & 21 & 1.1 & 18 & 2.6 & 2 & 0.3 & 1 & 0.1 \\
\hline & Ergalatax contracta (Reeve, 1846) & 15 & 0.8 & 3 & 0.4 & 8 & 1.3 & 4 & 0.6 \\
\hline & Ergalatax heptagonalis (Reeve,1846) & 5 & 0.3 & 0 & 0 & 4 & 0.7 & 1 & 0.1 \\
\hline & Indothais lacera $($ Born, 1778$)$ & 5 & 0.3 & 4 & 0.6 & 0 & 0 & 1 & 0.1 \\
\hline & Indothais sacellum (Gmelin, 1791) & 30 & 1.5 & 25 & 3.7 & 1 & 0.2 & 4 & 0.6 \\
\hline & Morula uva (Roding, 1798) & 17 & 0.8 & 5 & 0.7 & 3 & 0.5 & 9 & 1.3 \\
\hline & Orania subnodulosa (Melvill, 1893) & 14 & 0.7 & 3 & 0.4 & 6 & 1 & 5 & 0.7 \\
\hline & Purpura panama (Roding, 1798) & 28 & 1.4 & 20 & 2.9 & 4 & 0.7 & 4 & 0.6 \\
\hline & Semiricinula tissoti (Petit de la Saussaye, 1852) & 22 & 1.1 & 4 & 0.6 & 9 & 1.5 & 9 & 1.3 \\
\hline Nassariidae Iredale, 1916 (1835) & Nassarius marmoreus (Adams, 1852) & 5 & 0.2 & 2 & 0.3 & 2 & 0.3 & 1 & 0.1 \\
\hline Neritidae Rafinesque, 1815 & Nerita oryzarum Recluz, 1841 & 7 & 0.4 & 5 & 0.7 & 2 & 0.3 & 0 & 0 \\
\hline Pisaniidae & Pollia rubiginosa (Reeve, 1846) & 7 & 0.4 & 5 & 0.7 & 2 & 0.3 & 0 & 0 \\
\hline Trochidae Rafinesque, 1815 & Monodata australis (Lamarck, 1822) & 6 & 0.3 & 4 & 0.6 & 2 & 0.3 & 0 & 0 \\
\hline Turbinidae & Astralium stellare (Gmelin, 1791) & 32 & 1.6 & 22 & 3.2 & 7 & 1.1 & 3 & 0.4 \\
\hline Vanikoridae Gray, 1840 & Vanikoro cuvieriana (Recluz, 1843) & 1 & 0.1 & 1 & 0.1 & 0 & $\begin{array}{c}1.1 \\
0\end{array}$ & 0 & 0 \\
\hline Total & & 2000 & & 680 & & 611 & & 709 & \\
\hline
\end{tabular}




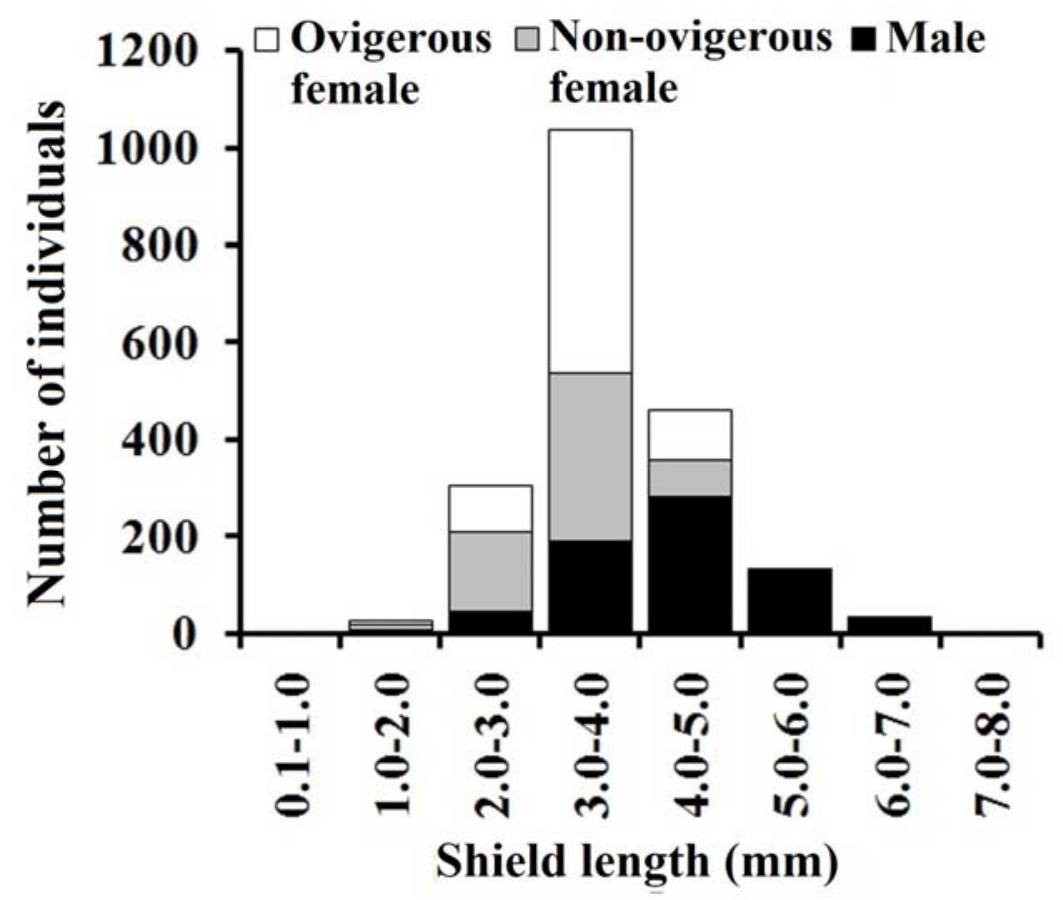

Figure 3: Size frequency distribution of different individuals of Clibanarius rhabdodactylus in Veraval, Saurashtra coast, Gujarat, India.

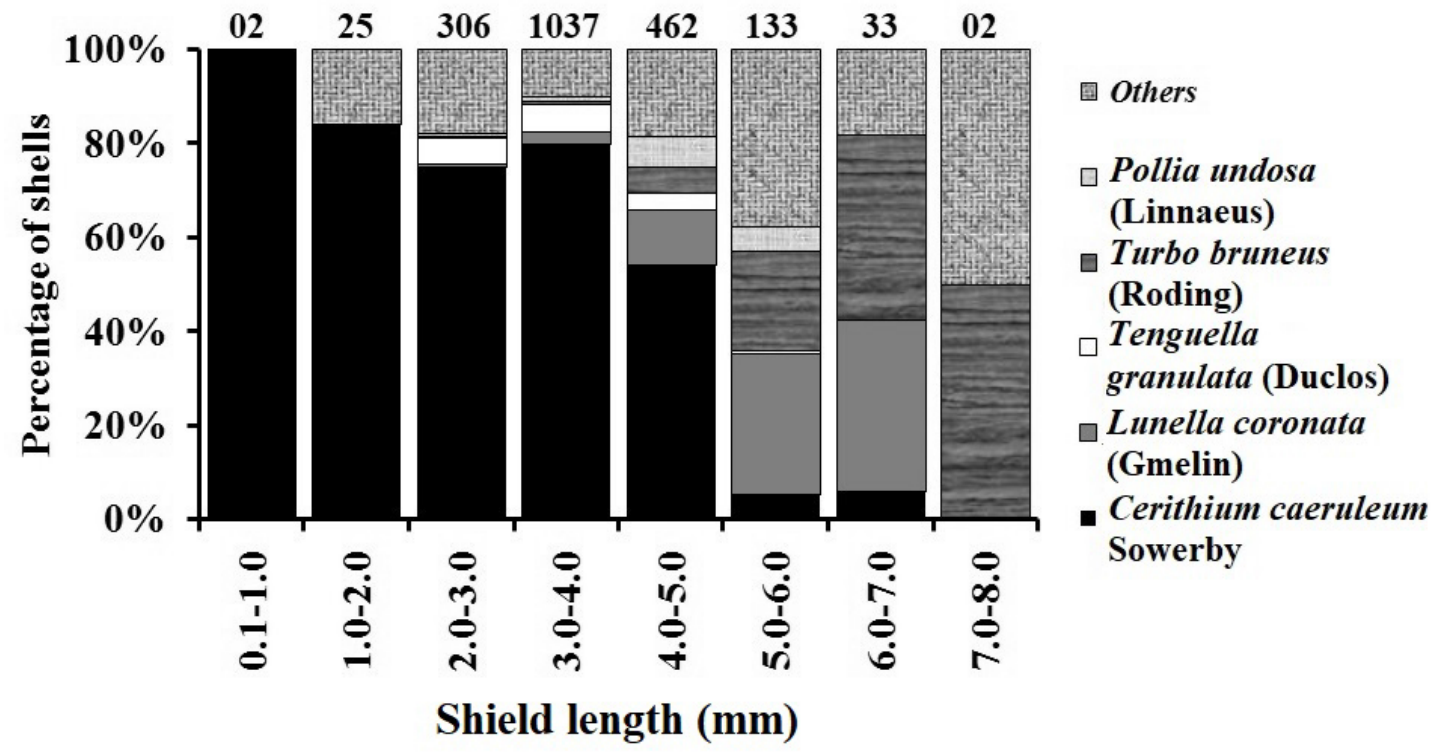

Figure 4: Use of different gastropod shells by individuals of Clibanarius rhabdodactylus of different size classes in Veraval, Saurashtra coast, Gujarat, India. (Numbers above the bar indicates number of individuals).

The shield length of $C$. rhabdodactylus showed a moderate relationship with all the morphological traits of the gastropod shells with maximum values of relationship recorded for gastropod shell length and shell dry weight (Fig. 5). Clibanarius rhabdodactylus weight showed a moderate relationship with gastropod shell length, shell dry weight and shell volume, with maximum values of relationship recorded for gastropod shell length and shell dry weight. Clibanarius rhabdodactylus weight did not show a significant relationship with gastropod shell aperture length and width (Fig. 6). 

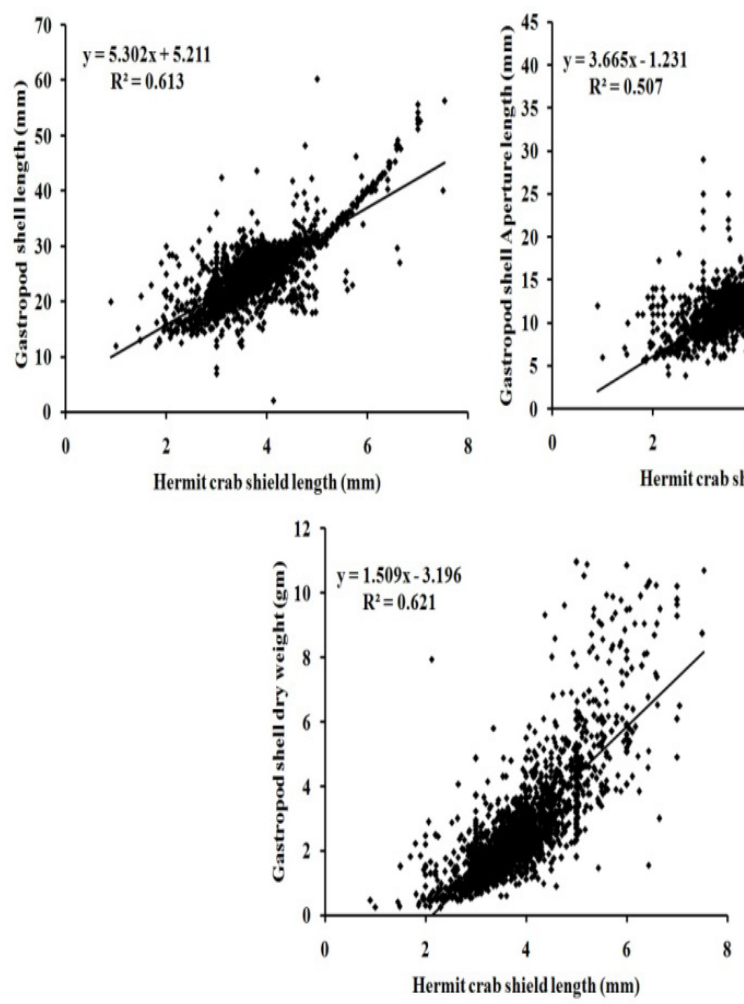
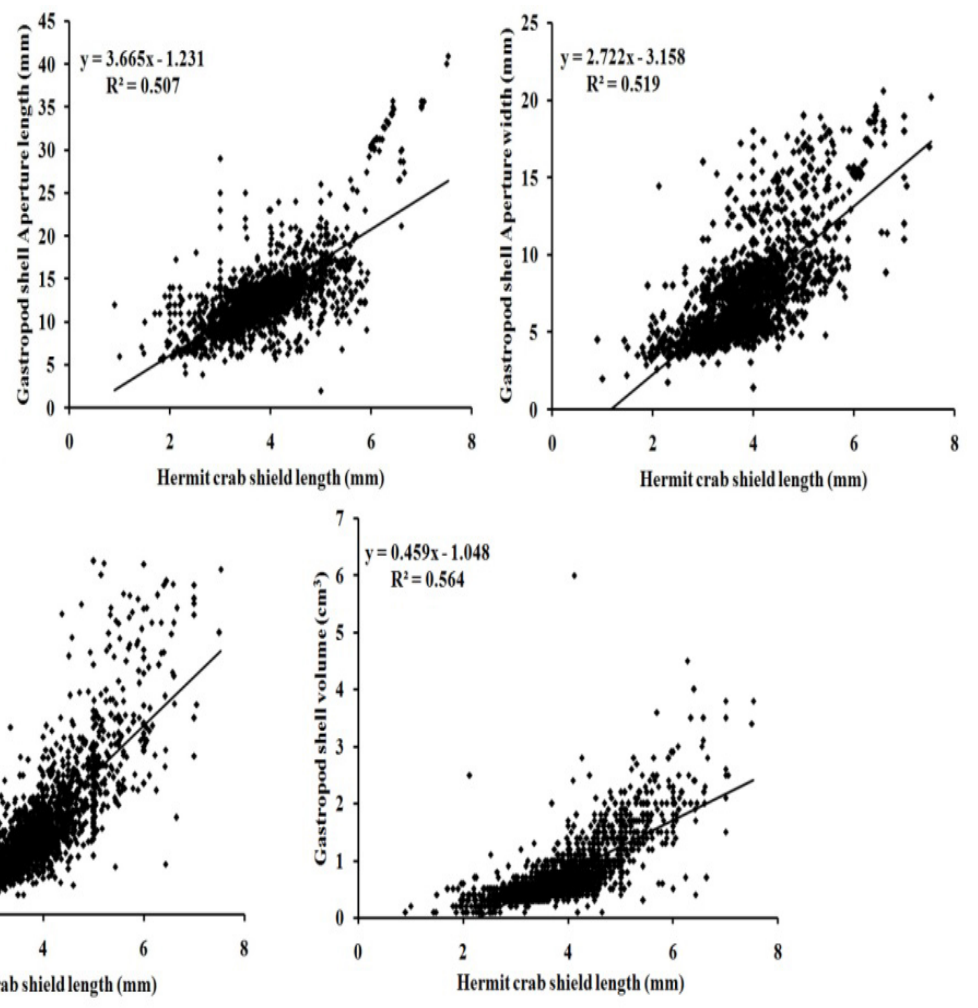

Figure 5: Regression analysis between Clibanarius rhabdodactylus shield length and different morphological parameters of gastropod shells in Veraval, Saurashtra coast, Gujarat, India.

Table 3: Comparison of values of shell length (SHL), dry weight (DW) and shell volume (SHV) of five highly occupied gastropod shells between different sexes of Clibanarius rhabdodactylus in Veraval, Saurashtra coast, Gujarat, India.

\begin{tabular}{lcccc}
\hline Gastropod species & Parameters & Male & Non-ovigerous female & Ovigerous female \\
\hline \multirow{2}{*}{ Cerithium caeruleum G. B. Sowerby II, 1855 } & SHL (mm) & $26.18 \pm 4.67$ & $23.61 \pm 4.42$ & $24.76 \pm 3.56$ \\
& DW (gm) & $2.52 \pm 0.99$ & $1.92 \pm 0.81$ & $2.12 \pm 0.69$ \\
& SHV (mm ${ }^{3}$ & $0.63 \pm 0.24$ & $0.5 \pm 0.18$ & $0.53 \pm 0.17$ \\
\hline \multirow{2}{*}{ Lunella coronata (Gmelin,1791) } & SHL & $20.92 \pm 4.56$ & $13.31 \pm 5.03$ & $17.44 \pm 0.79$ \\
& DW & $4.46 \pm 1.65$ & $2.58 \pm 1.04$ & $3.24 \pm 2.46$ \\
& SHV & $1.45 \pm 0.44$ & $0.77 \pm 0.29$ & $1.20 \pm 1.17$ \\
Tenguella granulata (Duclos, 1832) & SHL & $29.89 \pm 3.95$ & $23.63 \pm 3.12$ & $24.79 \pm 2.86$ \\
& DW & $2.56 \pm 1.01$ & $1.64 \pm 0.51$ & $1.90 \pm 0.48$ \\
Turbo bruneus (Roding, 1798) & SHV & $0.98 \pm 0.96$ & $0.48 \pm 0.15$ & $0.55 \pm 0.18$ \\
& SHL & $29.53 \pm 5.03$ & $21.53 \pm 5.31$ & 31.16 \\
\hline \multirow{2}{*}{ Pollia undosa (Linnaeus, 1758) } & DW & $5.42 \pm 2.24$ & $3.57 \pm 2.70$ & 3.27 \\
& SHV & $2.10 \pm 0.83$ & $1.31 \pm 0.98$ & 1.8 \\
\hline
\end{tabular}



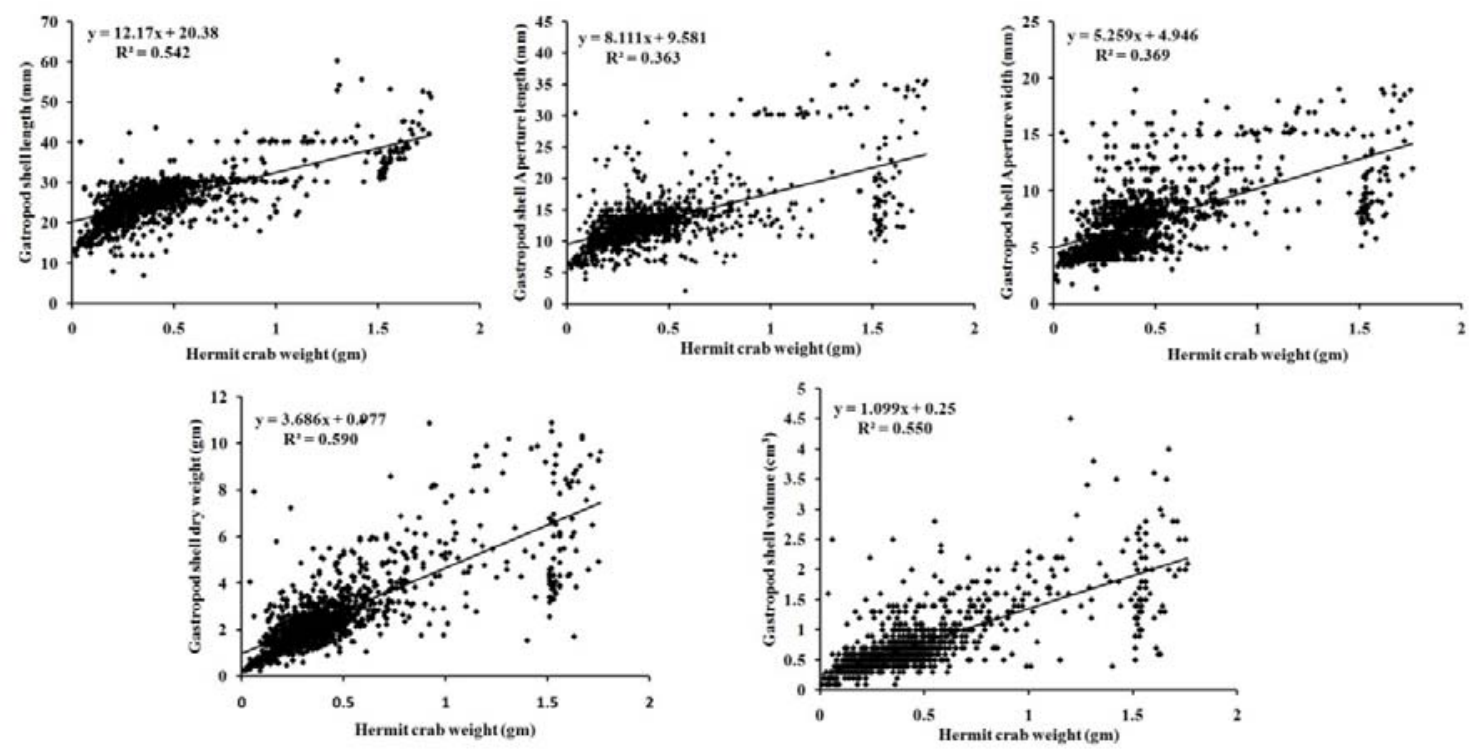

Figure 6: Regression analysis between Clibanarius rhabdodactylus weight and different morphological parameters of gastropod shells in Veraval, Saurashtra coast, Gujarat, India.

\section{Discussion}

In the present study, it was found that $C$. rhabdodactylus occupies shells of 29 species of gastropods which is higher than the gastropods species shells utilized by other species like Clibanarius antillensis Stimpson (25 species) (Argüelles-Ticó et al., 2010), C. zebra (23 species) (Trivedi and Vachhrajani, 2014), C. virescens (23 species) (Reddy and Biseswar, 1993), C. erythropus (19 species) (Botelho and Costa, 2000) and C. vittatus (13 species) (Sant'Anna et al., 2006). It was also observed that ovigerous females of $C$. rhabdodactylus were occupying shells of only 23 species of gastropods which is less than males (25 species) and nonovigerous females (27 species). Similar results were observed for ovigerous females of Clibanarius zebra (Trivedi and Vachhrajani, 2014) and Paguristes tortugae (Mantelatto and Dominciano, 2002).

The morphology of occupied gastropods shell species by hermit crabs is well correlated with the shield length and hermit crab weight (Abrams, 1978; Wada et al., 1997; Osorno et al., 2005). Similar calculations were carried out in the present study where the shield length and weight of $C$. rhabdodactylus showed a moderate relationship with shell dry weight, shell length and shell volume. Similar results were also observed in studies carried out on other hermit crab species like Paguristes tortugae Schmitt, (Mantelatto and Dominciano, 2002), Clibanarius erythropus (Latreille) (Botelho and Costa, 2000) and Pagurus exilis (Benedict) (Mantelatto et al., 2007).

It is suggested that a heavy shell occupied by a hermit crab protects it from damage from wave action and attack from predators (Reese, 1969). Clibanarius rhabdodactylus is found in the rocky intertidal zone (Fig. 2), preferring deep tide pools, cracks, crevices and under rock sites which have high wave action and significant predator density.

In the present study, it was observed that males are comparatively larger in size than females (Table 1) and that individual males and ovigerous females occupied larger shells (Table 3). Similar results were observed in shell utilization for Clibanarius erythropus where males occupied larger and stronger gastropod shells because they utilized more energy for somatic growth, while females utilized smaller shells to save energy for reproduction and egg development (Gherardi, 1991). However, ovigerous females occupied larger shells, compared to non-ovigerous females, since they require more spacious shells to accommodate and protect the egg mass (Abrams, 1978; Bertness, 1981; Wada et al., 1997; Mantelatto and Dominciano, 2002; Sant'Anna et al., 2006).

In the present study, $C$. caeruleum shells were highly occupied by $C$. rhabdodactylus which is possibly due to the higher abundance of $C$. caeruleum (25 individual $/ 0.25 \mathrm{~m}^{2}$ ) in the study area (Patel et al., unpublished data). A similar pattern has been observed for C. zebra, preferring Cerithium scabridum shells (Trivedi and Vachhrajani, 2014) and C. erythropus occupying Pisania auritula shells (Botelho and Costa, 2000).

It was observed that, although $C$. caeruleum shells were occupied by almost all size classes of the hermit crab, individuals belonging to the size class 0.1 to 1.0 $\mathrm{mm}$ were strictly utilizing $C$. caeruleum shells. 
However, as the size of the hermit crab increases, selection of shell species shifts to $L$. coronata, $T$. granulata, T. bruneus, and "other" gastropod shells, suggesting competition for optimal shells in the larger individuals. The larger and more robust shells provide various benefits, including protection from predation, cannibalism, desiccation, intra- or interspecific fights, and courtship and egg mass protection (Hazlett, 1981; Abrams, 1988). Also, shell utilization patterns by different sexes of hermit crabs can be strongly affected by individual size, reproductive status, and growth and energy expenditure of individuals (Bertness, 1981; Mantelatto and Garcia, 2000; Dominciano and Mantelatto, 2004).

\section{Conclusion}

The current study provides the first insight into the ecology of C. rhabdodactylus inhabiting rocky shores of the Saurashtra coast of Gujarat State, India. It is observed that this species utilizes a wide variety of gastropod shells available in the habitat. The utilization of gastropod shells is not random, but depends upon the correlation between different variables of hermit crab size and gastropod shell morphometry. It was also observed that the pattern of shell utilization between different sexes of $C$. rhabdodactylus was also different, and is likely due to differences in their relative growth and reproductive success. Further studies on intertidal distribution, population ecology, and seasonal variation in the shell utilization patterns are needed to provide baseline information about the ecology of $C$. rhabdodactylus.

\section{Conflict of interest}

All the authors declare that there are no conflicting issues related to this research article.

\section{Acknowledgements}

The authors thank the anonymous reviewers for their valuable comments and corrections on the manuscript.

\section{References}

Abrams, P. (1978). Shell selection and utilization in a terrestrial hermit crab, Coenobita compressus $(\mathrm{H}$. Milne Edwards). Oecologia, 34 (2): 239-253. https://doi.org/10.1007/BF00345169

Angel, J. E. (2000). Effects of shell fit on the biology of the hermit crab Pagurus longicarpus (Say). Journal of Experimental Marine Biology and Ecology, 243 (2): 169-184. https://doi.org/10.1016/S0022-0981(99)00119-7

Apte, D. (2014). Sea shells of India. Oxford University Press. 197 pp.

Argüelles, A., Álvarez, F. and Alcaraz, G. (2009). Shell architecture and its relation to shell occupation by the hermit crab Clibanarius antillensis under different wave action conditions. Scientia Marina, 73 (4): 717-723. https://doi.org/10.3989/scimar.2009.73n4717

Argüelles-Ticó, A. Álvarez, F. Alcaraz, G. (2010). Shell utilization by the hermit crab Clibanarius antillensis Stimpson 1862 (Crustacea Anomura) in intertidal rocky pools at Montepio, Veracruz, Mexico. Tropical Zoology, 23 (1): 63-73.

Bach, C. E., and Hazlett, B. A. (2009). Shell shape affects movement patterns and microhabitat distribution in the hermit crabs Calcinus elegans, $C$. laevimanus and C. latens. Journal of Experimental Marine Biology and Ecology, 382 (1): 27-33. https://doi.org/10.1016/j.jembe.2009.10.009

Bertness, M. D. (1980). Shell preference and utilization patterns in littoral hermit crabs of the Bay of Panama. Journal of Experimental Marine Biology and Ecology, 48 (1): 1-16. https://doi.org/10.1016/0022-0981(80)90002-7

Bertness, M. D. (1981). Conflicting advantages in resource utilization: the hermit crab housing dilemma. The American Naturalist, 118 (3): 432-437. https://doi.org/10.1086/283835

Bertness, M. D. (1982). Shell utilization, predation pressure, and thermal stress in Panamanian hermit crabs: an interoceanic comparison. Journal of Experimental Marine Biology and Ecology, 64 (2): 159-187. https://doi.org/10.1016/0022-0981(82)90151-4

Biagi, R., Meireles, A. L., Scelzo, M. A. and Mantelatto, F. L. (2006). Comparative study of shell choice by the southern endemic hermit crab Loxopagurus loxochelis from Brazil and Argentina. Revista Chilena de Historia Natural, 79 (4): 481-487. http://dx.doi.org/10.4067/S0716-078X2006000400007

Biseswar, R. and Reddy, T. (1993). Patterns of shell utilization in two sympatric species of hermit crabs from the Natal coast (Decapoda, Anomura, Diogenidae). Crustaceana, 65 (1): 13-24. https://doi.org/10.1163/156854093X00324

Botelho, A. Z. and Costa, A. C. (2000). Shell occupancy of the intertidal hermit crab Clibanarius erythropus (Decapoda, Diogenidae) on São Miguel (Azores), In: Jones, M. B., Azevedo, J. M. N., Neto, A. I., Costa, A. C. and Martins, A. M. F. (Eds.), Island, Ocean and Deep-Sea Biology. Developments in Hydrobiology, Springer, Dordrecht, Volume152. pp. 111-117.

Briffa, M. and Elwood, R. W. (2005). Metabolic consequences of shell choice in Pagurus bernhardus: do hermit crabs prefer cryptic or portable shells? Behavioral Ecology and Sociobiology, 59: 143-148. https://doi.org/10.1007/s00265-005-0020-0

Chiu, Y.-W., Chen, H.-C., Lee, S.-C. and Chen, C. A. (2002). Morphometric analysis of shell and operculum variations in the viviparid snail, Cipangopaludina chinensis (Mollusca: Gastropoda), in Taiwan. Zoological Studies, 41 (3): 321-331. 
Conover, M. R. (1978). The importance of various shell characteristics to the shell-selection behavior of hermit crabs. Journal of Experimental Marine Biology and Ecology, 32 (2): 131-142. https://doi.org/10.1016/0022-0981(78)90111-9

Desai, A. Y. and Mansuri, A. P. (1989). Salinity and desiccation tolerance of hermit crab of Veraval, West coast of India. Indian Journal of Current Biosciences, 8: 129-132.

Dominciano, L. C. C., Sant'Anna, B. S. and Turra, A. (2009). Are the preference and selection patterns of hermit crabs for gastropod shells species-or site-specific? Journal of Experimental Marine Biology and Ecology, 378 (1-2): 15-21. https://doi.org/10.1016/j.jembe.2009.07.002

Dominciano, L. C. and Mantelatto, F. L. M. (2004). The influence of shell species and size on the shell selection pattern of Paguristes tortugae (Decapoda, Diogenidae) from Anchieta Island (Ubatuba, Brazil). Iheringia Série Zoologia, 94 (4): 425-428. https://doi.org/10.1590/S0073-47212004000400012

Elwood, R. W., McClean, A. and Webb, L. (1979). The development of shell preferences by the hermit crab Pagurus bernhardus. Animal Behaviour, 27 (3): 940-946. https://doi.org/10.1016/0003-3472(79)90032-0

Elwood, R. W. and Neil, S. J. (1992). Assessments and decisions: a study of information gathering by hermit crabs. Chapman and Hall, London, pp. 192.

Gherardi, F. (1991). Relative growth, population structure, and shell-utilization of the hermit crab Clibanarius erythropus in the Mediterranean. Oebalia, 17: 181-196.

Hazlett, B. A. (1966). Social behavior of the Paguridae and Diogenidae of Curacao. Studies on the Fauna of Curaçao and other Caribbean Islands, 23 (1): 1-143.

Hazlett, B. A. (1981). The behavioural ecology of hermit crabs. Annual Review of Ecology and Systematics, 12: 1-22. https://doi.org/10.1146/annurev.es.12.110181.000245

Hazlett, B. A. (1992). The effect of past experience on the size of shells selected by hermit crabs. Animal Behaviour, 44 (2): 203-205. https://doi.org/10.1016/0003-3472(92)90026-6

Kachhiya, P., Raval, J., Poriya, P. and Kundu, R. (2017). Diversity and new records of intertidal hermit crabs of the genus Clibanarius (Crustacea: Decapoda: Diogenidae) from Gujarat coast off the northern Arabian Sea, with two new records for the mainland Indian coastline. Journal of Threatened Taxa, 9 (6): 10334-10339. https://dx.doi.org/10.11609/jott.2785.8.7.8953-8969

Kellogg, C. W. (1977). Coexistence in a hermit crab species ensemble. The Biological Bulletin, 153 (1): 133-144. https://doi.org/10.2307/1540697
Malay, M. C. M. D., Rahayu, D. L. and Chan. T.-Y. (2018). Hermit crabs of the genera Calcinus Dana, Clibanarius Dana, and Dardanus Paul'son from the PANGLAO 2004 Expedition, with description of a new species and a checklist of the hermit crabs of the Philippines (Crustacea: Anomura: Paguroidea). Raffles Bulletin of Zoology, 66: 23-65.

Mantelatto, F. L. and de Meireles, A. L. (2004). The importance of shell occupation and shell availability in the hermit crab Pagurus brevidactylus (Stimpson, 1859) (Paguridae) population from the southern Atlantic. Bulletin of Marine Science, 75 (1): 27-35.

Mantelatto, F. L. M. and Garcia, R. B. (2000). Shell utilization pattern of the hermit crab Calcinus tibicen (Diogenidae) from southern Brazil. Journal of Crustacean Biology, 20 (3): 460-467. https://doi.org/10.1163/20021975-99990060

Mantelatto, F. L. and Domiciano, L. C. C. (2002). Pattern of shell utilization by the hermit crab Paguristes tortugae (Diogenidae) from Anchieta Island, southern Brazil. Scientia Marina, 66 (3): 265-272.

https://doi.org/10.3989/scimar.2002.66n3265

Mantelatto, F. L., Biagi, R., de Meireles, A. L. and Scelzo, M. A. (2007). Shell preference of the hermit crab Pagurus exilis (Anomura: Paguridae) from Brazil and Argentina: a comparative study. Revista de Biología Tropical, 55 (1): 153-161. https://doi.org/10.15517/rbt.v55i0.5815

Meireles, A. L., Biagi, R. and Mantelatto, F. L. (2008). Influence of prior experience on shell selection by the white spotwrist hermit crab Pagurus criniticornis (Crustacea: Paguridae). Hydrobiologia, 605 (1): 259-263. https://doi.org/10.1007/s10750-008-9305-4

Osawa, M. and Yoshida, R. (2009). Two estuarine hermit crab species of the genus Clibanarius (Crustacea: Decapoda: Diogenidae) from the Ryukyu Islands, southern Japan. Species Diversity, 14 (4): 267-278. https://doi.org/10.12782/specdiv.14.267

Osorno, J. L., Contreras-Garduno, J. and MacíasGarcia, C. (2005). Long-term costs of using heavy shells in terrestrial hermit crabs (Coenobita compressus) and the limits of shell preference: an experimental study. Journal of Zoology, 266 (4): 377-383.

https://doi.org/10.1017/S0952836905007028

Patel, P., Patel, K., and Trivedi, J. (2020). First record of Hermit crab Clibanarius ransoni Forest, 1953 (Crustacea: Anomura: Diogenidae) from India. Journal of Biological Studies, 3 (1): 19-23.

Pechenik, J. A., Hsieh, J., Owara, S., Wong, P., Marshall, D., Untersee, S. and Li, W. (2001). Factors selecting for avoidance of drilled shells by the hermit crab Pagurus longicarpus. Journal 
of Experimental Marine Biology and Ecology, 262 (1): 75-89.

https://doi.org/10.1016/S0022-0981(01)00284-2

Reese, E. S. (1962). Submissive posture as an adaptation to aggressive behavior in hermit crabs. Journal of Animal Psychology, 19 (6): 645-651. https://doi.org/10.1111/j.1439-0310.1962.tb00795.x

Reese, E. S. (1969). Behavioural adaptations of intertidal hermit grabs. American Zoologist, 9 (2): 343-355.

https://doi.org/10.1093/icb/9.2.343

Sant'Anna, B. S., Zangrande, C. M., Reigada, A. L. D. and Pinheiro, M. A. A. (2006). Shell utilization pattern of the hermit crab Clibanarius vittatus (Crustacea, Anomura) in an estuary at São Vicente, State of São Paulo, Brazil. Iheringia. Série Zoologia, 96 (2): 261-266. http://dx.doi.org/10.1590/S0073-47212006000200018

Trivedi, D. J., Trivedi, J. N., Soni, G. M., Purohit, B. D. and Vachhrajani, K. D. (2015). Crustacean fauna of Gujarat state of India: A review. Electronic Journal of Environmental Sciences, 8: 23-31.

Trivedi, J. N. (2015). Distribution, diversity and habitat preference of Brachyuran Crabs along the Coastal Saurashtra, Gujarat. PhD Thesis, The Maharaja Sayajirao University of Baroda.

Trivedi, J. N. and Vachhrajani, K. D. (2014). Pattern of shell utilization in the hermit crab Clibanarius zebra (Dana, 1852) along the Saurashtra coast, Gujarat, India. Tropical Zoology, 27 (4): 129-139. https://doi.org/10.1080/03946975.2014.964923

Trivedi, J. N. and Vachhrajani, K. D. (2017). An annotated checklist of hermit crabs (Crustacea, Decapoda, Anomura) of Indian waters with three new records. Journal of Asia-Pacific Biodiversity, 10 (2): 175-182.

https://doi.org/10.1016/j.japb.2017.01.001

Turra, A. and Leite, F. P. P. (2001). Shell utilization patterns of a tropical rocky intertidal hermit crab assemblage: I. The case of Grande Beach. Journal of Crustacean Biology, 21 (2): 393-406. https://doi.org/10.1163/20021975-99990140

Turra, A. and Leite, F. P. P. (2004). Shell-size selection by intertidal sympatric hermit crabs. Marine Biology, 145 (2): 251-257. https://doi.org/10.1007/s00227-004-1323-9

Vaghela, A. and Kundu, R. (2012). Spatiotemporal variations of hermit crab (Crustacea: Decapoda) inhabiting rocky shore along Saurashtra coast, western coast of India. Indian Journal of GeoMarine Science, 41 (2): 146-151.

Vance, R. R. (1972). Competition and mechanism of coexistence in three sympatric of intertidal hermit crabs. Ecology, 53 (6): 1062-1074.

https://doi.org/10.2307/1935418
Wada, S., Ohmori, H., Goshima, S. and Nakao, S. (1997). Shell-size preference of hermit crabs depends on their growth rate. Animal Behaviour, 54 (1): 1-8.

https://doi.org/10.1006/anbe.1996.0319 